\title{
Bacteriological Analysis of Water of Kathmandu Valley
}

\author{
Gyanendra Ghimire ${ }^{1}$, Binita Adhikari ${ }^{1}$, Manoj Pradhan ${ }^{1}$. \\ ${ }^{1}$ Department of Microbiology, Nepal Army Institute of Health Sciences, Kathmandu.
}

\begin{abstract}
Introduction: Water is indispensible for human existence. Water pollution is the most serious environmental quality issue all over the world, yet the people are less aware and give little emphasis on the vital connection between water and health. Drinking water of most communities and municipalities in Nepal is obtained from surface sources, rivers, streams, ponds and lakes. Most of these sources of water are likely to the polluted with domestic and industrial wastes and many types of microorganisms present in water causes various types of infectious diseases. Therefore, we intend to find the bacteriological water quality of Kathmandu valley.
\end{abstract}

Methods: A total of 200 water samples collected from different sources (over head tank, well and tube wells, taps, springs through spouts and household filter) from different parts of Kathmandu Valley were subjected for bacteriological analysis by MPN (3 sets 3 tubes) method. Presence of fecal coliform was detected by Eijkman test.

Results: Out of total 200 water samples, $130(65.0 \%)$ were unsatisfactory, $19(9.5 \%)$ were intermediate (suspicious), $30(15.0 \%)$ were satisfactory and remaining $21(10.5 \%)$ were excellent. Of the unsatisfactory water samples subjected to Eijkman test, $22.0 \%$ of overhead tank, $30.0 \%$ of ground water, $30.0 \%$ of piped tap water, $40.0 \%$ of natural tap (spout) and none of the household filter water showed fecal coliforms. Water contamination rate was higher during summer than in winter season.

Conclusions: It is concluded that most of the water sources of Kathmandu valley are bacteriologically unsatisfactory for drinking.

Keywords: water contamination, MPN, coliform, kathmandu valley.

\section{INTRODUCTION}

Although Nepal is one of the richest countries in terms of per individual water availability, it is the poorest country in terms of use of water ${ }^{1}$. Many people collect water from different sources or store water in insanitary conditions in the household. Even water sources are free from contamination, household storage pots, tanks and insanitation around house hold may be sources of contamination if not properly cleaned and maintained ${ }^{2}$.

Despite of campaign for safe drinking water, still waterborne infectious diseases significantly contribute in health problems in the world, particularly in the developing countries ${ }^{3}$. Even in developed countries like USA $67.7 \%$ of the gastroenteritis is of water borne origin $^{4}$. In Nepal, diarrhoeal disease ranks second in the list of top-ten diseases 5 . A high rate of microbial contamination of drinking water has been reported by previous workers from Nepal ${ }^{6-12}$. This study was conducted through out one complete year (2012 AD) to report the present scenario of water sources of Kathmandu valley and has been well correlated with periodic outbreak of gastroenteritis including cholera, particularly during monsoon (rainy) season every year ${ }^{13-19}$.

\section{METHODS}

This study was conducted at Nepalese Army Institute of Health Sciences, Sanobharyang, Kathmandu from

\section{Correspondance:}

Gyanendra Ghimire

Department of Microbiology, Nepal Army Institute of Health

Sciences, Kathmandu.

Email:serratia7@gmail.com 
Jan. 2012 to Jan 2013. A total of 200 water samples collected from different sources (over head tank, well and tube wells, piped water taps, springs through spouts and household filter) from different parts of Kathmandu valley were subjected for bacteriological analysis by MPN (3 sets 3 tubes) method. Samples were collected randomly, aseptically in $300 \mathrm{ml}$ sterile screw capped bottles and immediately transported to department of microbiology for processing.

Presence of fecal coliform was detected by Eijkman test ${ }^{20,21}$.

\section{RESULTS}

A total of 200 water samples collected from different water sources (over head tank $=50$, shallow wells and tube wells $=50$, piped water taps $=50$, springs through spouts $=25$ and household filter $=25$ ) in Kathmandu valley during the year 2011/2012 were tested for the presence of coliform bacilli using MPN technique. Of the tested samples, $130(65.0 \%)$ were unsatisfactory, $19(9.5 \%)$ were intermediate (suspicious), $30(15.0 \%)$ were satisfactory and only $21(10.5 \%)$ were excellent (Table-1).

Table 1: Quality of water from different sources* $(n=200)$

\begin{tabular}{|l|l|l|l|l|l|l|}
\hline Categories & $\begin{array}{l}\text { Over head } \\
\text { tank }\end{array}$ & $\begin{array}{l}\text { Ground } \\
\text { water }\end{array}$ & Tap water & $\begin{array}{l}\text { Natural } \\
\text { sources }\end{array}$ & Household filters & Total \\
\hline Excellent & $11(22.0 \%)$ & $0(0.0)$ & $0(0.0 \%)$ & $0(0.0)$ & $10(40.0 \%)$ & $21(10.5 \%)$ \\
\hline Satisfactory & $5(10.0 \%)$ & $0(0.0)$ & $15(30.0 \%)$ & $0(0.0)$ & $10(40.0 \%)$ & $30(15.0 \%)$ \\
\hline Intermediate & $5(10.0 \%)$ & $5(10.0 \%)$ & $4(8.0 \%)$ & $0(0.0)$ & $5(20.0 \%)$ & $19(9.5 \%)$ \\
\hline Unsatisfactory & $29(58.0 \%)$ & $45(90.0 \%)$ & $31(62.0 \%)$ & $25(100.0 \%)$ & $0(0.0 \%)$ & $130(65.0 \%)$ \\
\hline Total & 50 & 50 & 50 & 25 & 25 & 200 \\
\hline
\end{tabular}

*Excellent $\quad$ - No coliform and E. coli per $100 \mathrm{ml}$ of water

Satisfactory - 1-3 coliforms and no E. coli per $100 \mathrm{ml}$ of water

Intermediate - 4-9 coliforms and no E. coli per $100 \mathrm{ml}$ of water.

Unsatisfactory - > 10 coliforms or 1 or more E. coli per $100 \mathrm{ml}$ of water

All natural tap (spout) were unsatisfactory for drinking where as $90.0 \%$ of ground water, $78.0 \%$ of overhead tank, $70.0 \%$ of piped tap water and $40.0 \%$ of household filter water were unsatisfactory (Table-2).

Table 2: Presence of total and fecal coliforms in different water samples

\begin{tabular}{|l|l|l|l|}
\hline Sample & Total $(\mathrm{n})$ & Coliform + ve $(\%)$ & Fecal coliform + ve $(\%)$ \\
\hline Over head tank & 50 & $39(78.0)$ & $11(18.0)$ \\
\hline Ground water & 50 & $45(90.0)$ & $15(30.0)$ \\
\hline Tap water & 50 & $35(70.0)$ & $15(30.0)$ \\
\hline Natural source & 25 & $25(100.0)$ & $20(80.0)$ \\
\hline Household filter & 25 & $10(40.0)$ & $0(0.0)$ \\
\hline Total & 200 & $164(82.0 \%)$ & $61(30.5 \%)$ \\
\hline
\end{tabular}

Of the unsatisfactory water samples subjected to Eijkman test, $22.0 \%$ of overhead tank, $30.0 \%$ of ground water, $30.0 \%$ of piped tap water, $40.0 \%$ of natural tap (spout) and none of the household filter water showed fecal coliforms (Table-2). Water contamination rate was higher during summer than in winter season (Table-3).

Table 3: MPN values in $\mathrm{cfu} / 100 \mathrm{ml}$ of different water samples tested (positive samples)

\begin{tabular}{|l|l|l|l|l|}
\multirow{2}{*}{ Sample } & \multicolumn{2}{l|}{$\mathrm{n}(\%)$} & \multicolumn{2}{l|}{ MPN value (cfu/100 ml) } \\
\cline { 2 - 5 } & summer & winter & summer & winter \\
\hline Over head tank & $25 / 30(83.0 .0)$ & $11 / 20(35.0)$ & $150-460$ & $23-75$ \\
\hline Ground water & $29 / 30(93.3)$ & $20 / 20(100.0)$ & ${ }^{*}$ TMTC & 1100 \\
\hline Tap water & $26 / 30(70.0)$ & $11 / 20(25.0)$ & $150-460$ & $28-120$ \\
\hline
\end{tabular}


MJSBH July-December 2013|Vol 12| Issue 2

\begin{tabular}{|l|l|l|l|l|}
\hline Natural source & $15 / 15(100.0)$ & $10 / 10(100.0)$ & 1100 & 460 \\
\hline Household filter & $5 / 15(80.0)$ & $1 / 10(30.0)$ & $3-28$ & 3 \\
\hline
\end{tabular}

*TMTC- Too many to count in all positive samples (>1100 cfu/100ml.)

\section{DISCUSSION}

In the present study, almost two-third of the samples tested showed presence of coliform bacilli. This is slightly higher than the contamination rate reported by Ghimire et al (74.9\%) $2006^{7}$ and Rawal et al in 1994 $(78.8 \%)^{8}$ and slightly lower than that found by Rijal et al. $(95.0 \%)$ in $2006^{9}$ and Adhikari et al (88.0\%) in $1986^{10}$. However, it was higher than the findings of Atreya et al $(61.0 \%)$ in 2006 from Terai region of Nepa ${ }^{11}$, ENPHO $1999^{12}$ and ENPHO and JICA $2005^{13}$, Baveja et al (70.0\%) from India in $1989^{14}$ and Luksamijarulkul et al (68.8\%) from Thailand in $1994^{15}$ and Ise T et al $1996^{16}$. These findings indicated that the rate of contamination is decreasing in Kathmandu valley. However, present finding is still alarming when the WHO guidelines for drinking water is considered ${ }^{3}$. This is therefore, can be well correlated with the diarrhoeal diseases ranking second in the top-ten diseases of $\mathrm{Nepal}^{5}$ and periodic out break of gastroenteritis including cholera particularly in summer season ${ }^{11,14,17,18,19}$. This was also reflected by recent outbreak of infective viral hepatitis among police personnel in the barracks including in the Prime Minister quarter (newspaper reports, 2007) and Escherichia coli outbreaks in Germany (Newspaper reports, 2011).

In the present study, only $10.5 \%$ of water samples tested were excellent. This was due to inclusion of household filtered water. If filtered water was not considered, the percentage of excellent water comes to be $5.5 \%$ which was consistent with the finding reported twenty five years ago. This indicated that the drinking water quality has not been improved well during last twenty five years period despite of various efforts put. This could be due to the population growth, unplanned urbanization, poverty and others. Still, it was very interesting to see that the household filter was also unsatisfactory for drinking. However, all of them were negative for fecal coliforms. These findings indicated that the level of awareness about hygienic handling of filter among house wives needs to be improved.

Present study also resulted that $30.5 \%$ of water was recently contaminated with faecal materials of human origin. This was however, much less than reported in twenty five years ago $(57.0 \%)$ and indicated that the level of awareness about use of toilets is being improved, yet not satisfactorily ${ }^{10}$. Higher rate of contamination during summer season was attributed to rain water contamination.

In the present study, none of the natural tap water samples were satisfactory for drinking. This appears to be contamination with human and animal excreta. This indicates of open defecation, and needs to make the people aware of using toilet.

In general, the higher rate of fecal contamination that exist in Kathmandu valley is attributed to source contamination, ineffective treatment of water, and contamination after treatment during distribution (due to the rusting of water distribution pipe and occasional supply of water and nearby leakage from sewerage pipe that has always positive pressure). With regards to the ground water, contamination appears to occur through seepage of wastewater from sewage or other likely sources ${ }^{22-26}$. In many places, wells have been made without fulfilling the criteria (source of ground water should be located not less than 50 feet from likely sources of contamination) laid by $\mathrm{WHO}^{3}$. Keeping in view of these findings, an immediate action with regard to the preventing drinking water sources from contamination and proper treatment at the water treatment plant is strongly suggested. Though, it is not easy to do, an overhauling of water distribution system by replacing the old pipes is also essential. These actions are needed as to prevent the water-borne health problems and related morbidity and mortalities in future.

\section{CONCLUSIONS}

Most of the water sources of Kathmandu valley are bacteriologically unsatisfactory for drinking. An immediate action to prevent drinking water contamination is required.

\section{REFERENCES}

1. World Water Day, 2013: New Spotlight news mazagine, Nepal.

2. Thapa M, Sharma AP. Bacteriological study of drinking water in rural communities of Nepal. Nepal Med College J 1998; 1: 11-16.

3. World Health Organization. Guidelines for 
drinking water quality 2012, Geneva.

4. Liang JL, Dziuban EJ, Craun GF. Surveillance for waterborne disease and outbreaks associated with drinking water and water not intended for Drinking - United States, 2003-2004. CDC MMWR 2006; 51: 31-58.

5. Ministry of Health, 2005: Annual Report, Department of Health service, Nepal.

6. Thapa M, Sharma AP. Bacteriological study of drinking water in rural communities of Nepal. Nepal Med College J 1998;1: 11-6.

7. Ghimire G, Pant J, Rai SK, Choudhury DR, Adhikari NR. Bacteriological Analysis of water of Kathmandu Velly. J Nepal Assoc for Med Lab Sciences 2007; 8: 45-7.

8. Rawal S, Shrestha RS, Prasai BR, Pokharel BM, Kubo T. Bacterial Investigation of drinking water in Nepal. J Inst Med 1994;16: 120-6.

9. Rijal KR, Parajuli K, Basnet P, Ghimire P. Coliform in drinking water of Pokhara city. J Nepal Assoc for Med Lab Sciences 2007; 8: 25-8.

10. Adhikari RK, Rai SK, Pokharel BM, Khadka JB. Bacterial study of drinking water at Kathmandu Valley. J Inst Med 1986; 313-6.

11. Atreya K, Panthee S, Sharma P. Bacterial contamination of drinking water and the economic burden of illnesses for the Nepalese households. Int'l J Environ Health Res. 2006; 16: 385-90. http://dx.doi.org/10.1080/09603120600869448 PMid:16990179

12. ENPHO. Monitoring of groundwater quality in the Kathmandu valley, Nepal 1999 (Nepal).

13. JICA and ENPHO. Groundwater quality surveillance in Kathmandu and Lalitpur Municipality areas 2005 (Nepal).

14. Baveja CP, Chattopadhya D, Kumari S, Dutta KK, Sehgal S. Bacteriological study of drinking water during epidemic of cholera in Delhi. J Commun Dis 1989; 21: 59-61. PMid:2681392

15. Luksamijarulkul P, Pumsuwan V, Pungchitton S. Microbiological quality of drinking water and using water of a Chao Phya River community, Bangkok. Southeast Asian J Trop Med Public Health 1994; 25: 633-7. PMid:7667704

16. Ise $\mathrm{T}$, Pokhrel BM, Rawal S, Shrestha RS, Dhakwa JR. Outbreaks of cholera in Kathmandu
Valley in Nepal. J Trop Pediatr 1996; 42: 3057. $\quad$ http://dx.doi.org/10.1093/tropej/42.5.305 PMid:8936965

17. Rai DR, Rai SK, Sharma BK, Ghimire P, Bhatta DR. Factors associated with intestinal parasitic infection among school children in a rural area of Kathmandu Valley, Nepal. Nepal Med College J 2005; 7: 43-6. PMid:16295721

18. Ishiyama S, Rai SK, Ono K, Uga S. Small-scale study on intestinal parasitosis in a remote hilly village in Nepal. Nepal Med College J 2003; 5: 28-30. PMid:16583971

19. Tamang MD, Sharma N, Makaju RK et al. An outbreak of El Tor cholera in Kavre district, Nepal. Kathmandu Univ Med J 2005; 3: 138-42.

20. Collins CH, Lyne PM, Grange GM. Microbiological Methods. 6th ed. Butter Worths, London.

21. Collee JG, Fraser AG, Marmion BP Simmons A, editors. Mackie and McCartney Practical Medical Microbiology. 14th ed. Churchill LivingStone, London.

22. Maharjan M, Sharma AP. Bacteriological quality of ground water in urban patan and antibiotic sensitivity against isolated enteric bacteria. J Nepal Med Assoc 2000; 39: 269-74.

23. Thakur K, Grover PS. Bacterial indices of drinking water from natural sources. Indian J Pathol Microbiol 2001; 44:131-4. PMid:11883127

24. Grover PS, Thakur K. Shima drinking water: a bacteriological analysis. J Commun Dis 2001; 33: 44-52. PMid:11898462

25. Rainey RC, Harding AK. Drinking water quality and solar disinfection: effectiveness in peri-urban households in Nepal. J Water Health 2005; 3: 23948. PMid: 16209028

26. Rainey RC, Harding AK. Acceptability of solar disinfection of drinking water treatment in Kathmandu valley, Nepal. Int'1 J Environ Health Res 2005; 15: 361-72. http:// dx.doi.org/10.1080/09603120500289168 PMid:16416753 